Article

\title{
Effect of Organic Matter on Cr(VI) Removal from Groundwaters by Fe(II) Reductive Precipitation for Groundwater Treatment
}

\author{
Anna Gröhlich ${ }^{1}$, Margarethe Langer ${ }^{1, *}$, Manassis Mitrakas ${ }^{2}$, Anastasios Zouboulis ${ }^{3}$, \\ Ioannis Katsoyiannis ${ }^{3}$ and Mathias Ernst ${ }^{1}$ \\ 1 Institute for Water Resources and Water Supply, Technische Universität Hamburg, \\ Am Schwarzenberg-Campus 3, 21073 Hamburg, Germany; anna.groehlich@tuhh.de (A.G.); \\ mathias.ernst@tuhh.de (M.E.) \\ 2 Department of Chemical Engineering, Aristotle University of Thessaloniki, Thessaloniki 54124, Greece; \\ manasis@eng.auth.gr \\ 3 Department of Chemistry, Aristotle University of Thessaloniki, Thessaloniki 54124, Greece; \\ zoubouli@chem.auth.gr (A.Z.); katsogia@chem.auth.gr (I.K.) \\ * Correspondence: margarethe.langer@tuhh.de; Tel.: +49-40-42878-3914
}

Academic Editor: Wilhelm Püttmann

Received: 21 April 2017; Accepted: 27 May 2017; Published: 1 June 2017

\begin{abstract}
Due to its toxicity, $\mathrm{Cr}(\mathrm{VI})$ is undesirable in groundwater. Its chemical reduction to $\mathrm{Cr}(\mathrm{III})$ species, followed by precipitation is the most widely practiced treatment technique for the removal of $\mathrm{Cr}(\mathrm{VI})$ from polluted waters. The resulting $\mathrm{Cr}(\mathrm{III})$ species present low solubility, is much less toxic, and can be subsequently removed either by precipitation, or by adsorption onto iron oxy-hydroxides and co-precipitation. The effects of several parameters, such as the $\mathrm{pH}$ value of water to be treated, the applied Fe(II) dose, and the presence of appropriate mineral surfaces, are well investigated and understood. However, the impact of the presence of humic acids (HAs) in this process has only been considered by rather few studies. The main aim of this study was to determine the effect of humic substances on $\mathrm{Fe}(\mathrm{II})$ reductive precipitation of $\mathrm{Cr}(\mathrm{VI})$ within a $\mathrm{pH}$ range relevant for drinking water treatment. Jar test experiments were performed, using artificial groundwater of defined composition and initial $\mathrm{Cr}(\mathrm{VI})$ concentration $100 \mu \mathrm{g} / \mathrm{L}$, ferrous sulphate dosages $0.25-2 \mathrm{mg}$ $\mathrm{Fe}(\mathrm{II}) / \mathrm{L}$, and $\mathrm{pH}$ values $6.5-8$. It was found that $\mathrm{Cr}(\mathrm{VI})$ and total chromium $(\mathrm{Cr}($ total $))$ can be reliably removed in the absence of HAs in the tested $\mathrm{pH}$ range with the addition of $\mathrm{Fe}(\mathrm{II})$ dosage of $1 \mathrm{mg}$ $\mathrm{Fe}(\mathrm{II}) / \mathrm{L}$. Further on, the results indicated that the reduction of $\mathrm{Cr}(\mathrm{VI})$ is only slightly affected by the presence of HAs. However, increased residual total $\mathrm{Cr}$ concentrations were found at lower Fe(II) dosages and/or higher $\mathrm{pH}$ values. Additionally, the removal of the $\mathrm{Cr}(\mathrm{III})$ species formed during $\mathrm{Cr}(\mathrm{VI})$ reduction was strongly inhibited by the presence of HAs under the examined experimental conditions, since residual concentrations higher than $60 \mu \mathrm{g} / \mathrm{L}$ were determined. The results of this study will have implications to the ongoing discussion of a new, stricter, European Union regulation limit, regarding the presence of total chromium in drinking water.
\end{abstract}

Keywords: $\mathrm{Cr}(\mathrm{VI})$ removal; $\mathrm{Fe}(\mathrm{II})$ dose; $\mathrm{Cr}($ total); humic acids; groundwater

\section{Introduction}

Chromium and its compounds present unique properties, which are used in a broad range of industrial applications, such as leather tanning, pigment production, gas/oil well drilling, etc. [1]. Due to this wide range of applications, $\mathrm{Cr}$ is discharged into the environment by several sources and its presence in widely documented in several groundwaters and soils [1,2]. Moreover, hexavalent chromium $(\mathrm{Cr}(\mathrm{VI}))$ can occur naturally in soils and groundwaters. Increased $\mathrm{Cr}(\mathrm{VI})$ concentrations 
in aquifers can be formed due to erosion of ophiolithic and metamorphic rocks, as reported by Kaprara et al. (2015) [3] and Kazakis et al. (2015) [4]. The toxicity of chromium is mainly related to $\mathrm{Cr}(\mathrm{VI})$, while the second important redox species, the trivalent chromium $(\mathrm{Cr}(\mathrm{III}))$, is considered to be 100 times less toxic [5]; $\mathrm{Cr}(\mathrm{VI})$ is toxic, mutagenic, and carcinogenic to humans by inhalation and oral intake [6]. The other redox species are not stable and therefore, not relevant for treatment processes [7]. The higher relevance of $\mathrm{Cr}(\mathrm{VI})$, when compared to $\mathrm{Cr}(\mathrm{III})$, can be also explained by the different solubility in the $\mathrm{pH}$ range of drinking water. While $\mathrm{Cr}(\mathrm{III})$ has a low solubility $(<1 \mu \mathrm{g} / \mathrm{L})$ due to the formation of insoluble hydroxide $\left(\mathrm{K}_{\mathrm{sp}}\right.$ of $\left.\mathrm{Cr}(\mathrm{OH})_{3}=6.3 \times 10^{-31}[8,9]\right)$, in the $\mathrm{pH}$ range between 7 and 10, $\mathrm{Cr}(\mathrm{VI})$ is highly soluble. The most important redox species at $\mathrm{pH}$ values $>6.5$ is chromate $\left(\mathrm{CrO}_{4}{ }^{2-}\right)$, while $\mathrm{Cr}_{2} \mathrm{O}_{7}{ }^{-}$and $\mathrm{HCrO}_{4}{ }^{-}$are mainly relevant to $\mathrm{pH}$ values $<6.5$ [10] and its speciation depends on $\mathrm{Cr}(\mathrm{VI})$ concentration and $\mathrm{pH}$ value.

Chromium is an important parameter, regarding its presence, in drinking water regulations. However, there is only a limit concentration value for the presence of total chromium ( $\mathrm{Cr}($ total)). For example, a value of $50 \mu \mathrm{g} \mathrm{Cr}$ (total)/L is defined as the maximum allowable limit in the drinking water regulations of European Union [11]. However, due to recent findings about the toxicity of $\mathrm{Cr}(\mathrm{VI})$ for oral intake [5], there is an ongoing discussion in research and policy about introducing lower limit values for $\mathrm{Cr}($ total), as well as a separate concentration limit value for $\mathrm{Cr}(\mathrm{VI})$. At the moment, only the US state of the California has already established a limit value of $10 \mu \mathrm{g} / \mathrm{L}$ for $\mathrm{Cr}(\mathrm{VI})$, which has been in place since 1 July 2014 [12].

Reductive precipitation, commonly by adding Fe(II), is a well-known treatment process for the removal of $\mathrm{Cr}(\mathrm{VI})$ from water. Firstly, $\mathrm{Cr}(\mathrm{VI})$ is reduced to $\mathrm{Cr}(\mathrm{III})$, while $\mathrm{Fe}(\mathrm{II})$ is oxidized to ferric iron (Fe(III)) [13]. This step is displayed in the chemical reaction (1),

$$
\mathrm{Cr}(\mathrm{VI})_{\mathrm{aq}}+3 \mathrm{Fe}(\mathrm{II})_{\mathrm{aq}} \rightarrow \mathrm{Cr}(\mathrm{III})_{\mathrm{aq}}+3 \mathrm{Fe}(\mathrm{III})_{\mathrm{aq}}
$$

Afterwards, $\mathrm{Cr}$ (III) and Fe(III) precipitate either as combined hydroxides, or $\mathrm{Cr}$ (III) is adsorbed to produced ferric hydroxides [13], as shown by the reaction (2).

$$
x \mathrm{Cr}(\mathrm{III})+(1-\mathrm{x}) \mathrm{Fe}(\mathrm{II})+3 \mathrm{H}_{2} \mathrm{O} \rightarrow \mathrm{Cr}_{x} \mathrm{Fe}_{1-\mathrm{x}}(\mathrm{OH})_{3(\mathrm{~s})}+3 \mathrm{H}^{+}(0<\mathrm{x}<1)
$$

The type of precipitate is hereby dependent on the specific $\mathrm{pH}$ value [14]. Moreover, the reduction of $\mathrm{Cr}(\mathrm{VI})$ by $\mathrm{Fe}(\mathrm{II})$ has a minimum reaction rate at $\mathrm{pH} 4$ and the reaction rate increases with increased $\mathrm{pH}$ value [15]. Thus, a fast reaction for the commonly encountered $\mathrm{pH}$ range in drinking water (6-8.5) is expected [13]. From the respective chemical Equation (1), it is further derived that stoichiometrically a molar ratio of $1[\mathrm{Cr}(\mathrm{VI})]$ to 3 [Fe(III)] is needed for the optimum removal of $\mathrm{Cr}(\mathrm{VI})$ [13]. However, this molar ratio may vary in a relatively broad range, considering the findings of different researchers. A molar ratio $[\mathrm{Cr}(\mathrm{VI})]:[\mathrm{Fe}(\mathrm{II})]=1: 3$ was found by several researchers in batch tests at $\mathrm{pH}$ range 6.0-8.0 [16] and 3.5-6.0 [17], as well as in full scale application at $\mathrm{pH}$ range 3.7-4.7 [18]. In contrast, higher molar ratios up to 1:10 were also found at $\mathrm{pH}$ range 6.5-8.2 [19]. Moreover, the process is influenced by several parameters, such as the presence of oxygen, temperature, and specific water composition $[13,14]$.

Only a few studies have investigated the combined effects of humic acids (Has) and $\mathrm{Fe}(\mathrm{II})$ presence. Buerge and Hug [20] claimed that the removal of $\mathrm{Cr}(\mathrm{VI})$ by different $\mathrm{Fe}(\mathrm{II})$-organic ligand complexes depends strongly on the characteristics of the used ligand, for example, on its capacity to stabilize $\mathrm{Fe}(\mathrm{II})$ and $\mathrm{Fe}(\mathrm{III})$ in an aqueous solution [20]. Depending on the $\mathrm{pH}$ of the water, the presence of other ligands that stabilize Fe(III) (e.g., by the creation of bi- and/or mulita-dentate carboxylates) may accelerate the respective reaction, whereas ligands that can stabilize Fe(II) (e.g., phenanthroline) may even stop the reductive reaction of $\mathrm{Cr}(\mathrm{VI})$ [20]. Further on, the removal of $\mathrm{Cr}(\mathrm{VI})$ with a combination of Fe(II) and humic substances was previously tested by Hori et al. [21] and Agrawal et al. [22]. They found a catalysing effect on the reductive reaction by the presence of $\mathrm{HAs}$ at $\mathrm{pH}$ values lower than 6, through a cycling process of iron [21]. Fe(II) is in a first step oxidized by $\mathrm{Cr}(\mathrm{VI})$ and the formed 
$\mathrm{Fe}(\mathrm{III})$ was subsequently reduced by humic substances so that $\mathrm{Fe}(\mathrm{II})$ was again available for $\mathrm{Cr}(\mathrm{VI})$ reduction. Due to this, the removal of $\mathrm{Cr}(\mathrm{VI})$ was found to be effective at $\mathrm{Fe}(\mathrm{II})$ dosages lower than the aforementioned 1:3 molar ratio ([Cr(VI)]:[Fe(II)]) [21,22]. The kinetics of a combined reduction by the co-presence of $\mathrm{Fe}(\mathrm{II})$ and HAs are hereby different from the kinetics of experiments where only $\mathrm{Fe}(\mathrm{II})$ or only HAs were available [22,23]. It is claimed that this effect is dependent on the specific type of humic substance [22] and it is also limited by the lower solubility of $\mathrm{Fe}(\mathrm{III})$ at higher $\mathrm{pH}$ values, which would lead to a precipitation of ferric hydroxide(s), so that no further recycling of Fe can take place [24]. Therefore, there is a need for further investigation, regarding the effect of HAs or of natural organic matter on $\mathrm{Cr}(\mathrm{VI})$ and on total chromium removal by the application of $\mathrm{Fe}(\mathrm{II})$ reductive precipitation. In this study, the main objective was to evaluate the impact of dissolved organics carbon (DOC), present as humic acids (HAs), in synthetic groundwater spiked with $\mathrm{Cr}(\mathrm{VI})$ on the removal of $\mathrm{Cr}(\mathrm{VI})$ and of total chromium by applying the $\mathrm{Fe}(\mathrm{II})$ reductive precipitation treatment. The synthetic groundwater according to the NSF-challenge water from the National Sanitation Foundation (NSF International) is a model for natural groundwater and has already been applied in many other studies.

Additionally, the removal behaviour was compared with experiments conducted using tap water containing natural DOC and spiked with $\mathrm{Cr}(\mathrm{VI})$.

\section{Materials and Methods}

\subsection{Examined Waters}

Two different types of water were examined. Unless otherwise stated, all experiments were performed using NSF water; its composition is displayed in Table 1 and is based on the composition of the NSF-challenge water, as described by Amy et al. [25]. Additional experiments were performed with tap water from northern Germany. The groundwater source of the tap water naturally contains organic matter. Due to the high initial iron concentration, the treated water was used for the experiments, which has a DOC concentration of $1.3 \mathrm{mg} / \mathrm{L}$. The $\mathrm{pH}$ value of water was 7.8 and it was not adjusted prior to the experiments.

Table 1. Composition of NSF water and a tap water from northern Germany.

\begin{tabular}{ccc}
\hline Substance & NSF-Water & Tap Water \\
\hline $\mathrm{Na}^{+}(\mathrm{mg} / \mathrm{L})$ & 88 & 26 \\
$\mathrm{Mg}^{2+}(\mathrm{mg} / \mathrm{L})$ & 12.5 & 4 \\
$\mathrm{Ca}^{2+}(\mathrm{mg} / \mathrm{L})$ & 40 & 67 \\
$\mathrm{HCO}_{3}-(\mathrm{mg} / \mathrm{L})$ & 183 & - \\
$\mathrm{SO}_{4}^{2-}(\mathrm{mg} / \mathrm{L})$ & 50 & 15 \\
$\mathrm{Cl}^{-}(\mathrm{mg} / \mathrm{L})$ & 71 & 35 \\
$\mathrm{NO}_{3}^{-}(\mathrm{mg} / \mathrm{L})$ & 2 & $<0.4$ \\
$\mathrm{~F}^{-}(\mathrm{mg} / \mathrm{L})$ & 1 & 0.15 \\
$\mathrm{SiO}_{2}(\mathrm{mg} / \mathrm{L})$ & 20 & Not specified \\
$\mathrm{SO}_{4}{ }^{2-}(\mathrm{mg} / \mathrm{L})$ & - & 15 \\
Carbonate alkalinity $(\mathrm{mmol} / \mathrm{L})$ & Not specified & 1.7 \\
\hline
\end{tabular}

\subsection{Set-Up and Procedure}

All experiments were conducted as jar test experiments using two different set-ups (compare Table 2). For set-up A, jar tests were performed with $1.8 \mathrm{~L}$ batch volume, a Hei-Torque Precision 100 (programmable) stirrer (Heidolph Instruments GmbH \& Co. KG, Schwabach, Germany), and a 2 L beaker (tall shape) with baffles (according to DVGW W 218 standard [26]). For set-up B, a jar test apparatus with six stirrers (Aqualytic, Dortmund, Germany) was used with $1 \mathrm{~L}$ batch volume in $1 \mathrm{~L}$ beakers (tall shape). 
Table 2. Devices and stirring conditions used for experimental set-up A and B (G-values estimated).

\begin{tabular}{|c|c|c|}
\hline Parameter & Set-Up A & Set-Up B \\
\hline Stirring device & Hei-Torque Precision 100 & Aqualytic \\
\hline Volume & $1.8 \mathrm{~L}$ & $1.0 \mathrm{~L}$ \\
\hline Rapid mixing & $2 \mathrm{~min}$ at $250 \mathrm{rpm}\left(500 \mathrm{~s}^{-1}\right)$ & $2 \mathrm{~min}$ at $150 \mathrm{rpm}\left(115 \mathrm{~s}^{-1}\right)$ \\
\hline Slow stirring & $\begin{array}{l}60 \mathrm{~min} \text { at } 50 \mathrm{rpm} \text { (initially), stirring speed was adjusted } \\
\text { keeping G-value at } 50 \mathrm{~s}^{-1} \text { during extensive sampling }\end{array}$ & $60 \mathrm{~min}$ at $30 \mathrm{rpm}\left(10 \mathrm{~s}^{-1}\right)$ \\
\hline
\end{tabular}

The jar test procedure was identical for both set-ups. The $\mathrm{pH}$ value of artificial groundwater was adjusted prior to the addition of Fe(II) with drops of $0.2 \mathrm{~N} \mathrm{H}_{2} \mathrm{SO}_{4}$ using a WTW pH 340i pH meter (Xylem Analytics Germany Sales GmbH \& Co. KG, Weilheim, Germany) for set-up A and with a Crison MultiMeter MM 41 (Crison Instruments, Barcelona, Spain) for set-up B. For the experiments without the presence of HAs, rapid stirring was performed for 2 min after the addition of Fe(II) (Figure 1a) - note that, if necessary, the $\mathrm{pH}$ was consistently adjusted during this stirring phase. Afterwards, slow stirring was performed for another $60 \mathrm{~min}$. For the experiments with the presence of HAs, an additional $2 \mathrm{~min}$ of rapid stirring was added to the procedure, prior to the addition of Fe(II) based on DVGW (Deutscher Verein des Gas- und Wasserfachs e.V.) working sheet W 218 [26] (Figure 1b). Although operational parameters differ slightly between the two set-ups, random tests showed very good comparability between both approaches.

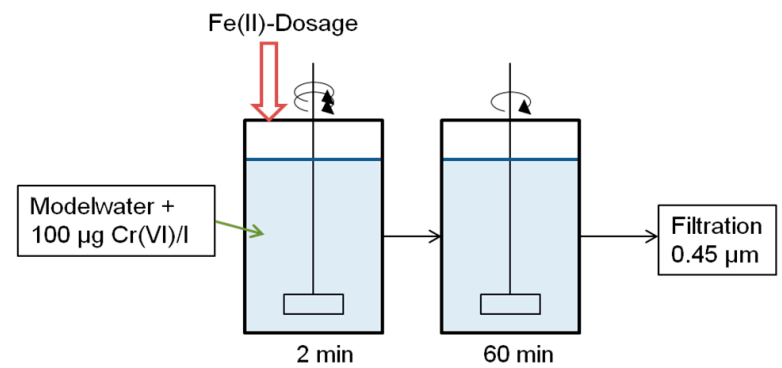

(a)

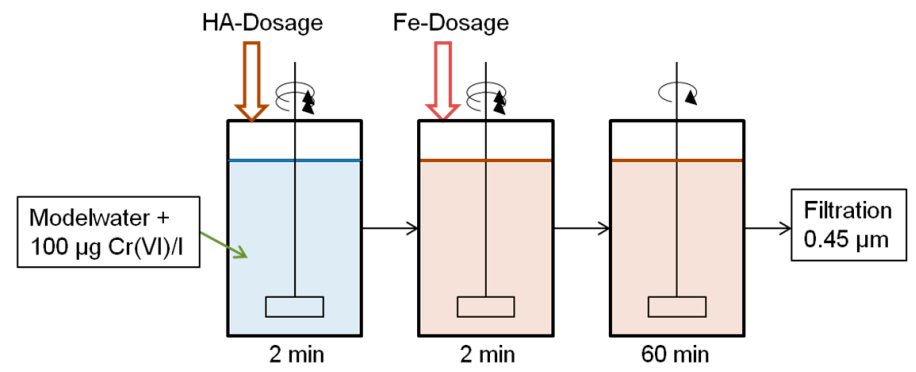

(b)

Figure 1. Jar test procedure for both experimental set-ups; (a) Procedure without the presence of humic acids (Has): 2 min of rapid stirring, followed by $60 \mathrm{~min}$ of slow stirring; (b) Procedure with the presence of HAs: an additional 2 min of rapid stirring for the addition of HA before Fe(II) is dosed.

All samples received after the performance of experiments and prior to analytical determinations were filtered using a $0.45-\mu \mathrm{m}$ filter directly after sampling to remove precipitates. For experimental set-up A, a cellulose nitrate filter and a vacuum filtration unit was used, whereas for set-up B, a nitro-cellulose mixed ester filter and a Buechner funnel was applied.

Stock solutions of $\mathrm{Cr}(\mathrm{VI})$ were prepared from potassium dichromate salt $\left(\mathrm{K}_{2} \mathrm{Cr}_{2} \mathrm{O}_{7}\right.$, for set-up A: Carl Roth ( $\geq 99.5 \%$ p.a.), for set-up B: Carlo Erba Reagents (99\%)). $\mathrm{FeSO}_{4} \cdot 7 \mathrm{H}_{2} \mathrm{O}$ was used for stock solutions of Fe(II) (for set-up A: Merck KGaA (min 99.5\%), for set-up B: Chem-Lab NV (99\%)). Stock solutions of $\mathrm{Fe}(\mathrm{II})$ were prepared in acidified ultrapure water during every experimental day 
and degassed with nitrogen to avoid oxidation. The same stock solution of HAs was used for both experimental set-ups. The stock solution was prepared by adding $20 \mathrm{~g}$ of HA salts (Carl Roth) to $2 \mathrm{~L}$ of ultrapure water. The solution was stirred for at least $12 \mathrm{~h}$ and filtered through a $0.45-\mu \mathrm{m}$ filter. The stock solution had a dissolved organic carbon (DOC) content of $1.74 \mathrm{~g} / \mathrm{L}$. All other chemicals used during the experiments were at least of reagent grade.

\subsection{Tested Reaction Conditions}

The concentration of $\mathrm{Cr}(\mathrm{VI})$ was kept constant at $100 \mu \mathrm{g} / \mathrm{L}$ for all the experiments performed. For the experiments without the presence of HAs, ferrous sulphate dosages of $0.25,0.5,1.0,1.5$, and $2.0 \mathrm{mg} \mathrm{Fe}(\mathrm{II}) / \mathrm{L}$ (molar ratios from 1:2.3 to 1:18.6 [Cr(VI)]:[Fe(II)] were tested in a pH range of 6.5-8. Most experiments were performed with artificial groundwater, termed as NSF water (see Section 2.1), spiked with $\mathrm{Cr}(\mathrm{VI})$. All experiments without the presence of humic acids were performed by using experimental set-up A. Tables 3 and 4 display a detailed overview of which set-up was used in each experiment. Experiments with the presence of HAs were performed at $\mathrm{pH}$ values of $6.5,7$, and 8 at ferrous sulphate dosages of $0.25,1.0$, and $2.0 \mathrm{mg}$ Fe(II)/L. HA concentrations are expressed as $\mathrm{mg}$ $\mathrm{DOC} / \mathrm{L}$ and concentrations of $1,3,5 \mathrm{mg}$ DOC/L were examined. The removal of chromium was additionally tested in tap water containing natural organic matter (tap water $\mathrm{A}$, used for comparison in Section 2.3).

Table 3. Experimental conditions used for the experiments shown in Figures 4, 6, 7, and 10.

\begin{tabular}{cccc}
\hline HA (mg DOC/L) & $\mathbf{0 . 2 5} \mathbf{~ m g ~ F e ( I I ) / L ~}$ & $\mathbf{1 ~} \mathbf{~ m g ~ F e ( I I ) / L ~}$ & 2 mg Fe(II)/L \\
\hline 0 & $\mathrm{~A}$ & $\mathrm{~A}$ & $\mathrm{~A}$ \\
1 & $\mathrm{~A}^{*}, \mathrm{~B}$ & $\mathrm{~A}^{*}$ & $\mathrm{~A}, \mathrm{~B}$ \\
3 & $\mathrm{~B}$ & $\mathrm{~A}^{*}$ & $\mathrm{~A}, \mathrm{~B}^{*}$ \\
5 & $\mathrm{~A}, \mathrm{~B}^{*}$ & $\mathrm{~A}^{*}$ & $\mathrm{~A}, \mathrm{~B}$ \\
\hline \multicolumn{4}{c}{ Note: * two repetitions. }
\end{tabular}

Table 4. Experimental conditions used for the experiments shown in Figures 5 and 8-10.

\begin{tabular}{cccc}
\hline HA (mg DOC/L) & pH 6.5 & pH 7 & pH 8 \\
\hline 0 & A & A & A \\
1 & $\mathrm{~B}^{*}$ & A, B & A, B * \\
3 & - & A, B & - \\
5 & $\mathrm{~B}^{*}$ & A, B & $\mathrm{B}^{*}$ \\
\hline \multicolumn{4}{c}{ Note: * two repetitions. }
\end{tabular}

\subsection{Analytical Methods}

Cr(total) was measured with Inductively Coupled Plasma-Mass Spectrometry ( NexION 300D ICP-MS, PerkinElmar, Waltham, Massachusetts, USA, [27]) for the experiments performed the set-up A and with Graphite Furnace-Atomic Adsorption Spectroscopy ( AAnalyst 800, PerkinElmer, Waltham, Massachusetts, USA [28]) for the experiments performed with set-up B. The detection limit for $\mathrm{Cr}$ (total) is $0.4 \mu \mathrm{g} / \mathrm{L}$ for ICP-MS and $1 \mu \mathrm{g} / \mathrm{L}$ for GF-AAS. Cr(VI) was measured spectrophotometrically, following its complexation with 1,5-Diphenylcarbazide, according to method $3500 \mathrm{Cr} \mathrm{B}$, as described by the American Public Health Association [29]. The respective measurements for set-up A were performed with a UV 1601 photometer (Shimadzu Deutschland GmbH, Duisburg, Germany) in a $100 \mathrm{~mm}$ cell; in this case, the detection limit was $1.5 \mu \mathrm{g} / \mathrm{L}$. A DR 3900 photometer (Hach Lange GmbH, Berlin, Germany) with a $50 \mathrm{~mm}$ cell was used for experimental set-up B, where the respective detection limit was $3.8 \mu \mathrm{g} / \mathrm{L}$.

Regarding the $\mathrm{Cr}(\mathrm{VI})$ determination in the presence of HAs, the applied spectro-photometric measurement method (3500 Cr B) needed to be modified accordingly, due to background values 
caused by HAs, which can otherwise lead to an over-estimation of $\mathrm{Cr}(\mathrm{VI})$ concentrations. Due to this, a standard addition method was integrated into the measurement method, according to DIN 32633. Additions of 25 and $50 \mu \mathrm{g} \mathrm{Cr}(\mathrm{VI}) / \mathrm{L}$ were applied. Moreover, the background values caused by the presence of HAs were subtracted from the adsorption value, caused by the addition of 1,5-diphenylcarbazide. Due to these necessary adjustments, the detection limit for $\mathrm{Cr}(\mathrm{VI})$ in the presence of HAs was increased to $10 \mu \mathrm{g} / \mathrm{L}$. The measurements of $\mathrm{Cr}$ (total) by the application of ICP-MS or GF-AAS procedures were not affected by the presence of HAs.

\section{Results}

\subsection{Removal of $\mathrm{Cr}(\mathrm{VI})$ in the Absence of $\mathrm{HAs}$}

\subsubsection{Kinetics of $\mathrm{Cr}(\mathrm{VI})$ Removal}

The reduction of $\mathrm{Cr}(\mathrm{VI})$ was found to be a fast process. Remaining concentrations of $\mathrm{Cr}(\mathrm{VI})>5 \mu \mathrm{g} / \mathrm{L}$ were measured after $2 \mathrm{~min}$ of slow stirring (Figure $2 \mathrm{a},<0.25 \mathrm{mg} \mathrm{Fe}(\mathrm{II}) / \mathrm{L}$ ). The further decrease in concentrations of $\mathrm{Cr}(\mathrm{VI})$ during the following slow mixing phase $(60 \mathrm{~min})$ was generally not significant for all the tested dosages of ferrous sulphate; e.g., the addition of $1 \mathrm{mg} \mathrm{Fe}(\mathrm{II}) / \mathrm{L}$ led to $[\mathrm{Cr}(\mathrm{VI})]$ residual concentration of $1.93 \mu \mathrm{g} / \mathrm{L}$ after $2 \mathrm{~min}$ of mixing (contact) and to [Cr(VI)] $1.07 \mu \mathrm{g} / \mathrm{L}$ after $60 \mathrm{~min}$. A rapid initial decrease of $\mathrm{Cr}(\mathrm{VI})$ concentrations was also found for all tested $\mathrm{pH}$ values (i.e., 6.5 to 8 ) and for all applied dosages of $\mathrm{Fe}$ (II) (i.e., 0.25-2 mg Fe(II)/L). Moreover, as it can be derived from Figure 2a, low residual concentrations of $\mathrm{Cr}(\mathrm{VI})$ can be found for all $\mathrm{Fe}(\mathrm{II})$ dosages, except for $0.25 \mathrm{mg} / \mathrm{L}$. At 0.25 $\mathrm{mg} \mathrm{Fe}(\mathrm{II}) / \mathrm{L}$, the residual $\mathrm{Cr}(\mathrm{VI})$ concentration after $60 \mathrm{~min}$ was $10.2 \mu \mathrm{g} / \mathrm{L}$, while it was below $5 \mu \mathrm{g} / \mathrm{L}$ for $\mathrm{Fe}(\mathrm{II})$ dosages $\geq 0.5 \mathrm{mg} \mathrm{Fe}(\mathrm{II}) / \mathrm{L}$. The rapid reduction of $\mathrm{Cr}(\mathrm{VI})$ is well matching with the relevant results reported in literature. For example, Mitrakas et al. [13] found a reduction of $\mathrm{Cr}(\mathrm{VI})$ within $5 \mathrm{~min}$ after the addition of $\mathrm{Fe}(\mathrm{II})$. A rapid reaction rate was also found by Sedlak and Chan [30]. Increased residual $\mathrm{Cr}(\mathrm{VI})$ concentrations might also be well explained by literature, as an applied $\mathrm{Fe}(\mathrm{II})$ dosage of $0.25 \mathrm{mg} \mathrm{Fe}(\mathrm{II}) / \mathrm{L}$ for an initial $\mathrm{Cr}(\mathrm{VI})$ concentration of $100 \mu \mathrm{g} / \mathrm{L}$ is equal to a molar ratio lower than 1:3 (1:2.3: $[\mathrm{Cr}(\mathrm{VI})]:[\mathrm{Fe}(\mathrm{II})])$. As derived from the respective literature review, this ratio would be needed for the complete reduction of $\mathrm{Cr}(\mathrm{VI})$ to $\mathrm{Cr}$ (III) if all $\mathrm{Fe}(\mathrm{II})$ is exclusively used for $\mathrm{Cr}(\mathrm{VI})$ reduction [13]; therefore, this might explain the increased residual $\mathrm{Cr}(\mathrm{VI})$ concentrations at $\mathrm{Fe}(\mathrm{II})$ dosage $0.25 \mathrm{mg}$ $\mathrm{Fe}(\mathrm{II}) / \mathrm{L}$. Moreover, $\mathrm{Cr}(\mathrm{VI})$ removal was found to be effective by applying a molar ratio of 1:5 or even higher ([Cr(VI)]:[Fe(II)]), which corresponds to a $\mathrm{Fe}(\mathrm{II})$ dosage of $0.5 \mathrm{mg} \mathrm{Fe}(\mathrm{II}) / \mathrm{L}$.

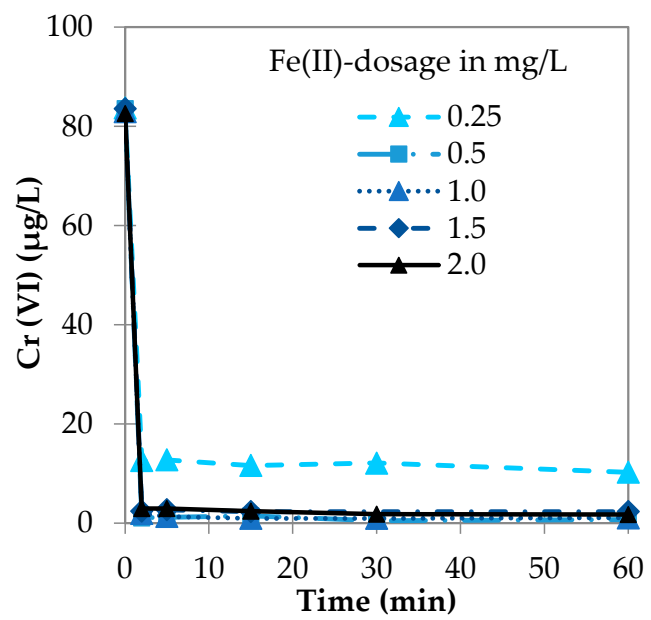

(a)

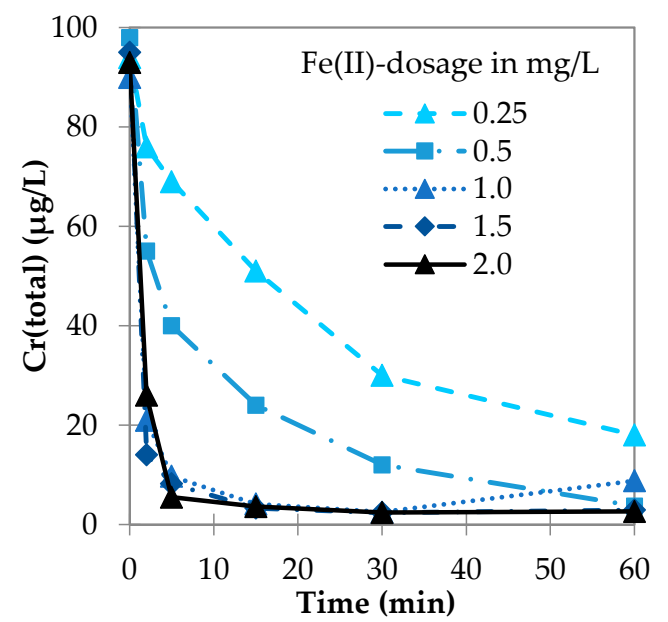

(b)

Figure 2. Removal kinetics of (a) $\mathrm{Cr}(\mathrm{VI})$ and (b) $\mathrm{Cr}$ (total) concentrations at $\mathrm{pH}$ value 7 and $\mathrm{Fe}$ (II) dosages $0.25,0.5,1,1.5$, and $2 \mathrm{mg} / \mathrm{L}$. All experiments were performed using set-up A. 
However, the residual $\mathrm{Cr}$ (total) concentrations displayed a decrease more similar to an exponential decline (Figure $2 \mathrm{~b}$ ). Especially for the dosages of 0.25 and $0.5 \mathrm{mg} \mathrm{Fe}(\mathrm{II}) / \mathrm{L}$, the decrease of $\mathrm{Cr}$ (total) concentrations is delayed. Since the concentrations of $\mathrm{Cr}(\mathrm{VI})$ were below $5 \mu \mathrm{g} / \mathrm{L}$ for the $\mathrm{Fe}(\mathrm{II})$ dosage of $\geq 0.5 \mathrm{mg} \mathrm{Fe}(\mathrm{II}) / \mathrm{L}$, these concentrations can be most likely attributed to the removal of $\mathrm{Cr}$ (III). Thus, it was assumed that the removal of $\mathrm{Cr}$ (III) was the rate-determining step for the removal of $\mathrm{Cr}$ (total) under the applied experimental conditions. This could be attributed to the application of a two-step treatment process, in which the precipitation of $\mathrm{Cr}(\mathrm{III})$ is the second step and can only take place when a sufficient amount of $\mathrm{Fe}(\mathrm{III})$ and $\mathrm{Cr}(\mathrm{III})$ is formed during the process [13]. From the residual concentrations of $\mathrm{Cr}$ (total), it might be derived that the adsorption/co-precipitation of $\mathrm{Fe}(\mathrm{III})$ and $\mathrm{Cr}(\mathrm{III})$ is more efficient at $\mathrm{Fe}(\mathrm{II})$ dosages of $1 \mathrm{mg} \mathrm{Fe}(\mathrm{II}) / \mathrm{L}$ or higher.

$\mathrm{Fe}(\mathrm{II})$ dosages of $\geq 0.5 \mathrm{mg} / \mathrm{L}$ were able to remove $\mathrm{Cr}$ (total) below the concentration of $5 \mu \mathrm{g} / \mathrm{L}$ within $60 \mathrm{~min}$ of slow stirring. The increase from 30 to $60 \mathrm{~min}$ of slow stirring at a Fe(II) dosage of $1 \mathrm{mg} \mathrm{Fe}(\mathrm{II}) / \mathrm{L}$ is considered as an outlier. Increased concentrations of $\mathrm{Cr}$ (total) after $60 \mathrm{~min}$ of slow stirring were only found at the $\mathrm{Fe}(\mathrm{II})$ dosage of $0.25 \mathrm{mg} \mathrm{Fe}(\mathrm{II}) / \mathrm{L}$. At this dosage of $\mathrm{Fe}(\mathrm{II}), \mathrm{Cr}(\mathrm{VI})$ is the highest fraction of $\mathrm{Cr}$ (total), i.e., $(\mathrm{Cr}$ (total $)=18 \mu \mathrm{g} / \mathrm{L} ; \mathrm{Cr}(\mathrm{VI})=10 \mu \mathrm{g} / \mathrm{L}$, and $\mathrm{Cr}(\mathrm{III})=8 \mu \mathrm{g} / \mathrm{L})$. This result indicates that at low dosage of $\mathrm{Fe}(\mathrm{II})$ the reduction of $\mathrm{Cr}(\mathrm{VI})$ is less efficient.

\subsubsection{Influence of $\mathrm{pH}$ and $\mathrm{Fe}(\mathrm{II})$ Dose}

The residual concentrations of $\mathrm{Cr}(\mathrm{VI})$ after $60 \mathrm{~min}$ of slow stirring are displayed in Figure 3a for the $\mathrm{pH}$ range of $6.5-8.0$ and for $\mathrm{Fe}(\mathrm{II})$ dosages $0.25-1.0 \mathrm{mg} / \mathrm{L}$. For all $\mathrm{pH}$ values, the highest residual $\mathrm{Cr}(\mathrm{VI})$ concentrations can be found for the Fe(II) dosage $0.25 \mathrm{mg} / \mathrm{L}$. When dosing $1 \mathrm{mg} \mathrm{Fe}(\mathrm{II}) / \mathrm{L}$ or more, all residual $\mathrm{Cr}(\mathrm{VI})$ concentrations were below $5 \mu \mathrm{g} / \mathrm{L}$. In contrast, for lower ferrous sulphate dosages (i.e., 0.25 and $0.5 \mathrm{mg} \mathrm{Fe}(\mathrm{II}) / \mathrm{L}$ ) a strong dependency of the residual $\mathrm{Cr}(\mathrm{VI})$ concentrations on the respective $\mathrm{pH}$ value was recorded (Figure 3). At these $\mathrm{Fe}(\mathrm{II})$ dosages and at $\mathrm{pH} 8$, residual $\mathrm{Cr}(\mathrm{VI})$ concentrations increased up to $58 \mu \mathrm{g} / \mathrm{L}$ (for $0.25 \mathrm{mg}$ Fe(II)/L), or to $23 \mu \mathrm{g} / \mathrm{L}$ (for $0.5 \mathrm{mg} / \mathrm{L} \mathrm{Fe}(\mathrm{II}) / \mathrm{L}$ ), respectively. Moreover, for the $\mathrm{Fe}(\mathrm{II})$ dosage $0.25 \mathrm{mg} / \mathrm{L}$, the lowest residual concentration can be found at $\mathrm{pH} 7$.

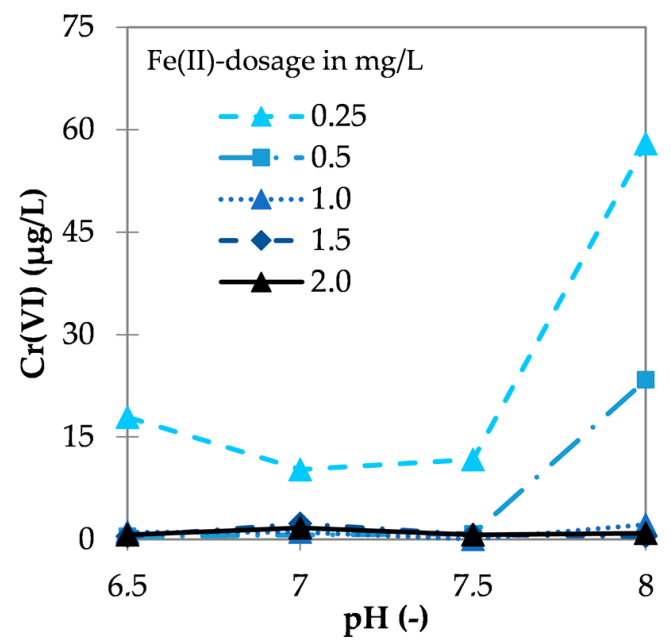

(a)

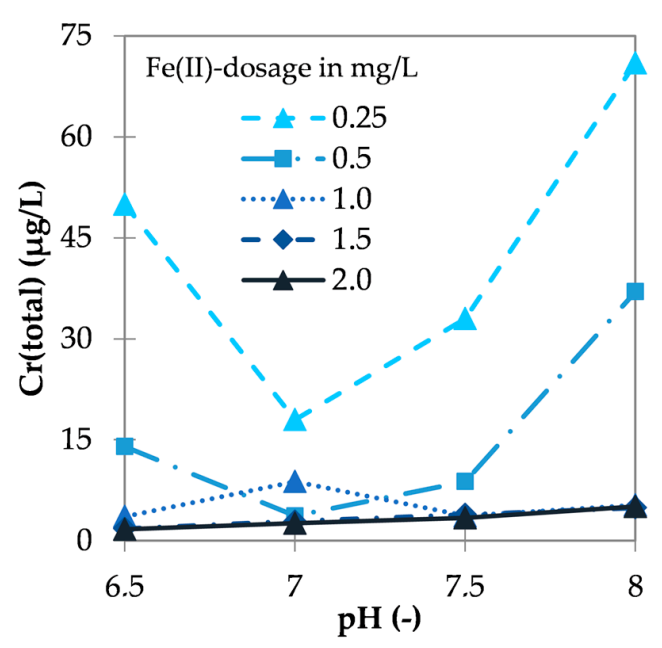

(b)

Figure 3. Residual concentrations of (a) $\mathrm{Cr}(\mathrm{VI})$ and (b) $\mathrm{Cr}$ (total) after $60 \mathrm{~min}$ of slow stirring as a function of $\mathrm{pH}$ value. $\mathrm{Fe}(\mathrm{II})$ dosages of $0.25,0.5,1,1.5$, and $2 \mathrm{mg} / \mathrm{L}$ and $\mathrm{pH}$ values of $6.5,7,7.5$, and 8 were examined; all experiments were performed using set-up A.

Similar to $\mathrm{Cr}(\mathrm{VI})$, the residual $\mathrm{Cr}$ (total) concentrations decreased with increasing Fe(II) dosages (Figure $3 \mathrm{~b}$ ). The strongest dependency on the $\mathrm{pH}$ value was again found for the lower Fe(II) dosages $(0.25$ and $0.5 \mathrm{mg} / \mathrm{L})$. For these dosages, the lowest residual concentrations can be found at $\mathrm{pH} 7$, and 
the highest residual concentrations at $\mathrm{pH} 8(71 \mu \mathrm{g} / \mathrm{L}$ for $0.25 \mathrm{mg} \mathrm{Fe}(\mathrm{II}) / \mathrm{L}$ and $37 \mu \mathrm{g} / \mathrm{L}$ for $0.5 \mathrm{mg}$ $\mathrm{Fe}(\mathrm{II}) / \mathrm{L}$ ). For the higher $\mathrm{Fe}(\mathrm{II})$ dosages $(1.5$ and $2 \mathrm{mg} / \mathrm{L}$ ), the residual concentrations of $\mathrm{Cr}$ (total) slightly increased with increased $\mathrm{pH}$ values, but the residual concentrations after $60 \mathrm{~min}$ still remained below $6 \mu \mathrm{g} / \mathrm{L}$. It is assumed that a similar effect might be also observed for the Fe(II) dosage of $1 \mathrm{mg} / \mathrm{L}$. Residual $\mathrm{Cr}(\mathrm{III})$ concentrations are influenced by the low solubility of $\mathrm{Cr}(\mathrm{III})$ in the tested $\mathrm{pH}$ range (6.5-8) [9].

Due to these results, it is assumed that at $\mathrm{pH} 7$ the Fe(II) dosage of $0.5 \mathrm{mg} / \mathrm{L}$ is sufficient for an effective removal of $\mathrm{Cr}(\mathrm{VI})$, as well as for $\mathrm{Cr}(\mathrm{III})$ (equals to a molar ratio of approx. 1:5 [Cr(VI)]:[Fe(II)]). However, to assure a sufficient removal of both species over the whole examined $\mathrm{pH}$ range (i.e., 6.5-8), a dosage of $1 \mathrm{mg} \mathrm{Fe}(\mathrm{II}) / \mathrm{L}$ is needed, which corresponds to a molar ratio of 1:10 [Cr( $\mathrm{VI})]$ :[Fe(II)]. These increased molar ratios might be explained by competing reactions, for example, the oxidation of Fe(II) by oxygen taking place simultaneously with increasing rates as the $\mathrm{pH}$ of water increases. The precise influence of competing reactions could not be determined within the frame of this study, since, for example, the effect of dissolved oxygen was not investigated.

\subsection{Removal of Chromium in the Presence of $H A$}

\subsubsection{Influence of $\mathrm{Fe}(\mathrm{II})$ Dosage}

Three different $\mathrm{Fe}(\mathrm{II})$ dosages $(0.25,1$, and $2 \mathrm{mg} / \mathrm{L})$ were tested in the presence of HA concentrations ranging between 0 and $5 \mathrm{mg} \mathrm{DOC} / \mathrm{L}$. The residual concentrations of $\mathrm{Cr}(\mathrm{VI})$ were found below the detection limit for all the tested concentrations of HAs (and for dosages 1.0 or $2.0 \mathrm{mg} F(\mathrm{II}) / \mathrm{L}$ ), noting the aforementioned higher detection limit of $\mathrm{Cr}(\mathrm{VI})$ in the presence of HAs. In contrast, the residual concentrations of $\mathrm{Cr}(\mathrm{VI})$ in the presence of HAs increased for the dosage of $0.25 \mathrm{mg} \mathrm{Fe}(\mathrm{II}) / \mathrm{L}(10 \mu \mathrm{g} / \mathrm{L}$ $\mathrm{Cr}(\mathrm{VI})$ at $0 \mathrm{mg} \mathrm{DOC} / \mathrm{L}$ ) up to approximately $58 \mu \mathrm{g} / \mathrm{L}$ of $\mathrm{Cr}(\mathrm{VI})$ (at $1 \mathrm{mg} \mathrm{DOC} / \mathrm{L}$ ), (Figure 4).

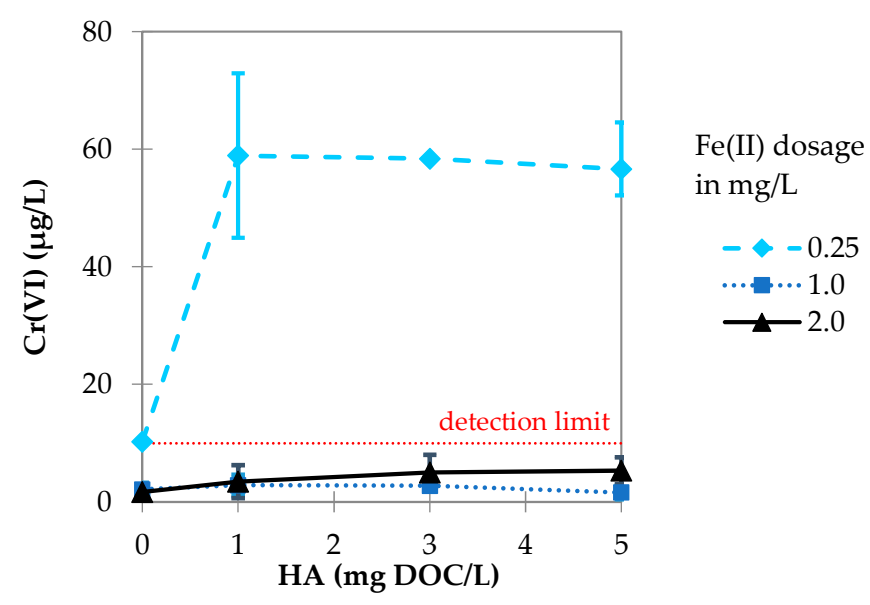

Figure 4. $\mathrm{Cr}(\mathrm{VI})$ residual concentrations after $60 \mathrm{~min}$ of slow stirring, as a function of the presence of HAs (concentrations: 0, 1, 3, $5 \mathrm{mg}$ DOC/L) at $\mathrm{pH} 7$ and for Fe(II) dosages $0.25,1$, and $2 \mathrm{mg} / \mathrm{L}$. Mean values with vertical bars indicate the range. The results were obtained with the application of both set-ups A and B.

These results are not in good agreement with the results reported by other researchers. Jiang et al. [23] showed that HAs by themselves are capable of reducing $\mathrm{Cr}(\mathrm{VI})$ to $\mathrm{Cr}(\mathrm{III})$. Prior to the tests with $\mathrm{Fe}(\mathrm{II})$, several batch tests were conducted to verify if the presence of HAs influences the oxidation state of chromium. At the given test conditions and initial concentrations of $\mathrm{Cr}(\mathrm{IV})$ and Has, no reduction of $\mathrm{Cr}(\mathrm{VI})$ was observed within 60 min of stirring.

According to the results by Agrawal et al. [22], under anoxic conditions a catalysing effect for the reductive reaction is expected, due to a redox recycling process for iron and hence a lower $\mathrm{Fe}(\mathrm{II})$ demand is expected, as compared to experiments without HAs (at a stoichiometric ratio lower than 1:3 
$[\mathrm{Cr}(\mathrm{VI})]:[\mathrm{Fe}(\mathrm{II})])$. However, at the tested $\mathrm{pH}$ range, $\mathrm{Fe}(\mathrm{III})$ is practically insoluble (with the respective $\mathrm{Ksp}=6 \times 10^{-38}[8]$ ) and is therefore removed from the solution, indicating that redox cycling might not take place in this case [24].

Additionally, at the dosage of $0.25 \mathrm{mg} \mathrm{Fe}(\mathrm{II}) / \mathrm{L}$ it can be observed that the residual $\mathrm{Cr}(\mathrm{VI})$ concentrations remained almost constant with the increased HA concentrations. This indicates that the reduction of $\mathrm{Cr}(\mathrm{VI})$ at lower $\mathrm{Fe}(\mathrm{II})$ dosages is inhibited by the presence of HAs, but also that this inhibitory effect is almost independent from the concentration of HAs. Finally, it is assumed from the obtained results that a $\mathrm{Fe}(\mathrm{II})$ dosage of $1 \mathrm{mg} / \mathrm{L}$ is needed to efficiently remove $100 \mu \mathrm{g} / \mathrm{L} \mathrm{Cr}(\mathrm{VI})$ in the presence of 1-5 mg DOC/L, similar to the results obtained in the absence of HAs in solution.

\subsubsection{Influence of $\mathrm{pH}$ Value}

The removal of $\mathrm{Cr}(\mathrm{VI})$ is strongly influenced by the $\mathrm{pH}$ value in the range $6.5-8$, as Figure 5 depicts. $\mathrm{Cr}(\mathrm{VI})$ residual concentrations at $\mathrm{pH}$ values of 6.5 and 7 were below the respective detection limit for all the examined dosages of HAs. However, the most remarkable results were obtained for $\mathrm{pH} 8$, where the residual $\mathrm{Cr}(\mathrm{VI})$ concentrations increased strongly with increasing HA concentrations, i.e., residual $\mathrm{Cr}(\mathrm{VI})$ concentrations were below $5 \mu \mathrm{g} / \mathrm{L}$ at $0 \mathrm{mg}$ DOC/L, up to $16 \mu \mathrm{g} / \mathrm{L}$ at the presence of $1 \mathrm{mg}$ DOC/L, and increased further to $25 \mu \mathrm{g} / \mathrm{L}$ in the presence of $5 \mathrm{mg}$ DOC/L (Figure 5).

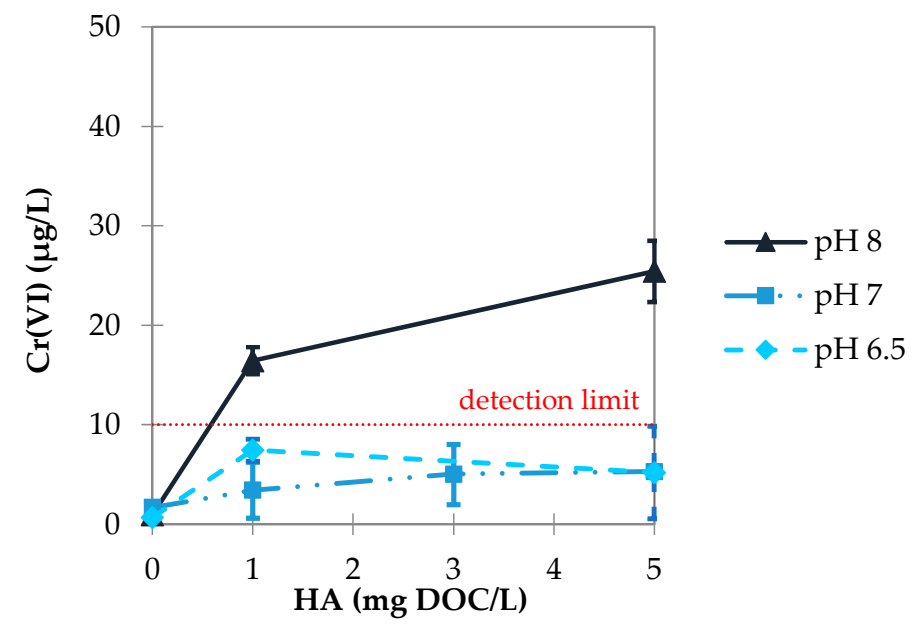

Figure 5. $\mathrm{Cr}(\mathrm{VI})$ residual concentrations as a function of HA presence (concentrations: $0,1,3,5 \mathrm{mg}$ DOC/L) at $\mathrm{pH}$ values 6.5, 7, and 8 at for $\mathrm{Fe}(\mathrm{II})$ dosage $2 \mathrm{mg} / \mathrm{L}$. Mean values with vertical bars indicate the range of values. The results were obtained by using both set-ups A and B.

The observed increase of residual $\mathrm{Cr}(\mathrm{VI})$ concentrations at the $\mathrm{pH}$ value 8 is of particular significance when the dosage of Fe(II) would also be considered, as it was also found for the lower applied $\mathrm{Fe}(\mathrm{II})$ dosages $(0.25$ and $0.5 \mathrm{mg} \mathrm{Fe} / \mathrm{L})$. However, the results displayed in Figure 5 were obtained with the $\mathrm{Fe}(\mathrm{II})$ dosage of $2 \mathrm{mg} / \mathrm{L}$, which is up to 8 times higher when compared with the experiments performed without the presence of HAs. The results therefore indicated that the influence of increased $\mathrm{pH}$ values on the reduction of $\mathrm{Cr}(\mathrm{VI})$ was stronger in the presence of HAs. However, it can be confirmed that the Fe(II) demand significantly increased at $\mathrm{pH} 8$ and in the presence of HAs and consequently, $\mathrm{Fe}$ (II) dosages $>2 \mathrm{mg} / \mathrm{L}$ are needed to achieve comparably high reduction and removals of $\mathrm{Cr}(\mathrm{VI})$.

\subsection{Influence of HAs on the Removal of Cr(total)}

\subsubsection{Influence of Fe(II) Dosage}

For all the examined dosages of $\mathrm{Fe}(\mathrm{II})$, the residual concentrations of $\mathrm{Cr}$ (total) increased with increasing concentrations of HAs (Figure 6). Fe(II) dosages of 0.25 and $1.0 \mathrm{mg} / \mathrm{L}$ were not able to reduce 
the $\mathrm{Cr}$ (total) concentrations below $60 \mu \mathrm{g} / \mathrm{L}$ at $\mathrm{pH}$ 7. Even with a Fe(II) dosage of $2.0 \mathrm{mg} / \mathrm{L}$, the residual $\mathrm{Cr}$ (total) concentration was $31 \mu \mathrm{g} / \mathrm{L}$ for waters containing $1 \mathrm{mg}$ DOC/L and up to $86 \mu \mathrm{g} / \mathrm{L}$ for waters containing $5 \mathrm{mg} \mathrm{DOC/L}$. Moreover, it is remarkable that at 0.25 and $1.0 \mathrm{mg} \mathrm{Fe}(\mathrm{II}) / \mathrm{L}$ concentrations, the respective $\mathrm{Cr}$ (total) concentrations remained roughly constant, even with increased concentrations of HAs (Figure 6).

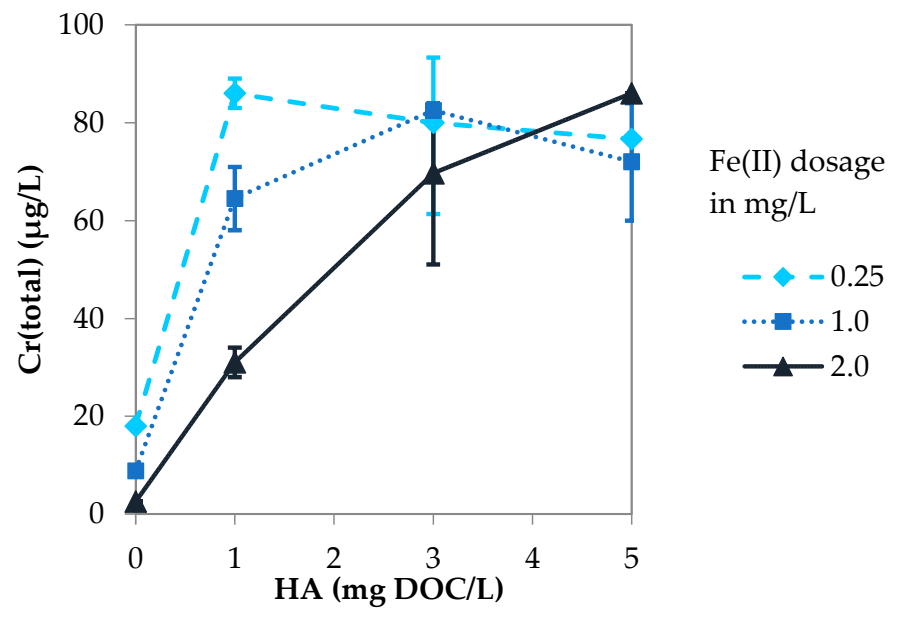

Figure 6. $\mathrm{Cr}$ (total) residual concentrations as a function of the presence of HAs $(0,1,3,5 \mathrm{mg}$ DOC/L) at $\mathrm{pH} 7$ and with $\mathrm{Fe}(\mathrm{II})$ dosages of $0.25,1.0$, and $2.0 \mathrm{mg} / \mathrm{L}$. Mean values with vertical bars were used to indicate the range. The results were obtained with both set-ups A and B.

For Fe(II) dosages of 1.0 and $2.0 \mathrm{mg} / \mathrm{L}$, the results indicated that a relatively high amount of $\mathrm{Cr}$ (III) still remained dissolved after $60 \mathrm{~min}$ of slow stirring (Figure 7). This fact reduces the acute toxic potential of chromium in solution. However, due to the possible re-oxidation of it, for example, through disinfection with chlorine, there is still a considerable risk of the re-formation of $\mathrm{Cr}(\mathrm{VI})$ [31,32]. In particular, Lindsay et al. [32] showed that $\mathrm{Cr}$ (III) complexed with ethylenediaminetetraacetic acid was very rapidly oxidized to $\mathrm{Cr}(\mathrm{VI})$ when in contact with chlorinated water during the disinfection of New York Tap water.

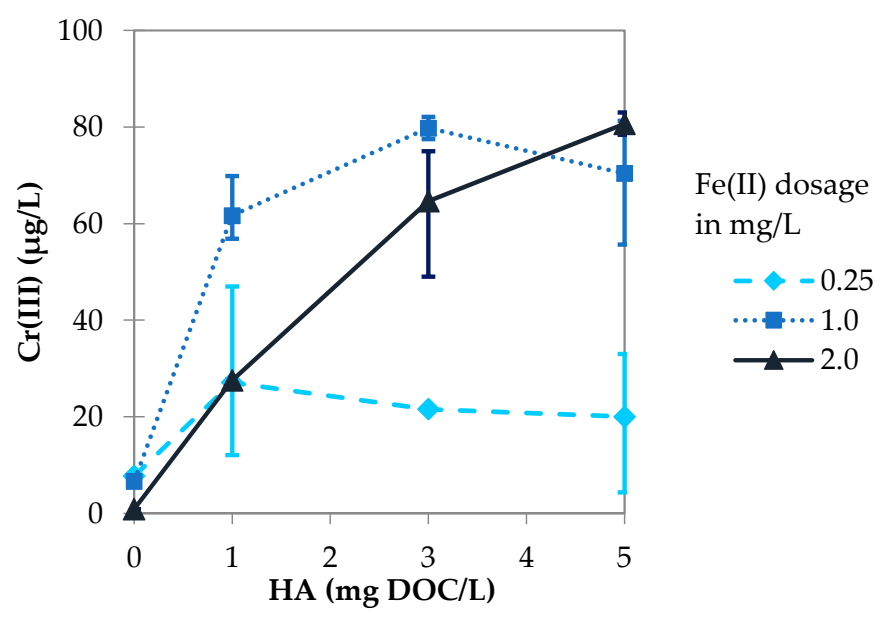

Figure 7. Cr(III) residual concentrations as a function of the presence of HAs (0, 1, 3, $5 \mathrm{mg}$ DOC/L) at $\mathrm{pH} 7$ and $\mathrm{Fe}(\mathrm{II})$ dosages $0.25,1.0$, and $2.0 \mathrm{mg} / \mathrm{L}$. Mean values with vertical bars indicate the respective range. The results were obtained with both set-ups $A$ and $B$.

A significantly higher amount of residual $\mathrm{Cr}(\mathrm{VI})$ was measured for all examined concentrations of HAs, but only when a smaller concentration of Fe(II) $(0.25 \mathrm{mg} / \mathrm{L})$ was dosed. An increase in residual 
$\mathrm{Cr}(\mathrm{VI})$ concentration was also observed in the experiments without the presence of HAs for the smaller $\mathrm{Fe}(\mathrm{II})$ dosage $(0.25 \mathrm{mg} / \mathrm{L})$. This effect seems to be strongly intensified in the co-presence of HAs, leading to a higher residual amount of toxic $\mathrm{Cr}(\mathrm{VI})$.

Thus, the reduction of $\mathrm{Cr}(\mathrm{VI})$ was strongly inhibited in the presence of HAs at the smaller Fe(II) dosages $(0.25 \mathrm{mg} / \mathrm{L})$, while $\mathrm{Cr}(\mathrm{VI})$ was shown to be reduced effectively by applying higher $\mathrm{Fe}(\mathrm{II})$ dosages (1.0 and $2.0 \mathrm{mg} / \mathrm{L}$ ). However, at dosages of 1 or $2 \mathrm{mg} \mathrm{Fe}(\mathrm{II}) / \mathrm{L}$ the removal of $\mathrm{Cr}(\mathrm{III})$ was strongly inhibited. This effect was also reported by Buerge and Hug [20]. They attributed their observations to the formation of complexes between HAs and $\mathrm{Cr}(\mathrm{III})$, which lead to a higher fraction of soluble $\mathrm{Cr}(\mathrm{III})$ in the presence of HAs [20]. Finally, all of these effects were shown to lead to higher residual concentrations of $\mathrm{Cr}$ (total) at $\mathrm{pH} 7$ and $\mathrm{Fe}(\mathrm{II})$ dosages between 0.25 and $2.0 \mathrm{mg} / \mathrm{L}$.

\subsubsection{Influence of $\mathrm{pH}$ Value}

The effect of increasing $\mathrm{pH}$ values cannot be clearly characterized for the removal of $\mathrm{Cr}$ (total) (Figure 8). For all the tested $\mathrm{pH}$ values, the residual concentrations of $\mathrm{Cr}$ (total) were found to increase similarly with the increased concentrations of HAs. Indeed, it is difficult to clearly differentiate between the examined $\mathrm{pH}$ values, because of the relatively large variability of results. Moreover, it is remarkable that the residual concentrations increased again with the increased concentrations of HAs, even when the relatively higher dosage of $2 \mathrm{mg} \mathrm{Fe}(\mathrm{II}) / \mathrm{L}$ was applied. As a comparison, in the experiments without the presence of $\mathrm{HAs}$, the residual $\mathrm{Cr}(\mathrm{VI})$ concentrations were found below $6 \mu \mathrm{g} / \mathrm{L}$, indicating high increase of $\mathrm{Cr}(\mathrm{VI})$ concentrations in the presence of HAs for all the examined $\mathrm{pH}$ values.

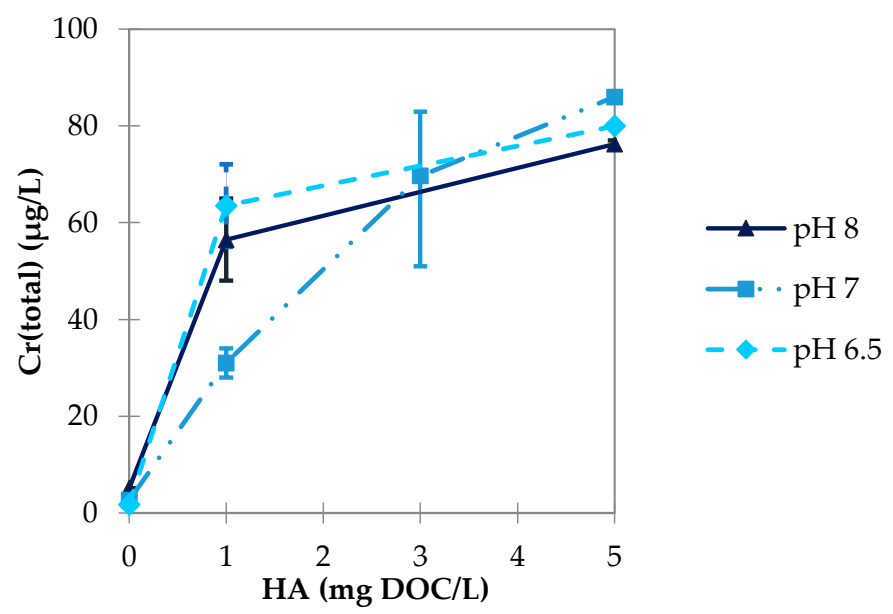

Figure 8. $\mathrm{Cr}$ (total) residual concentrations as a function of the presence of HAs $(0,1,3,5 \mathrm{mg}$ DOC/L) at $\mathrm{pH}$ values $6.5,7$, and 8 and at $\mathrm{Fe}(\mathrm{II})$ dosage $2 \mathrm{mg} / \mathrm{L}$. Mean values with vertical bars indicate the range. The results were obtained by the application of both set-ups $\mathrm{A}$ and $\mathrm{B}$.

Again, a higher fraction of $\mathrm{Cr}(\mathrm{VI})$ was found in this case with increased $\mathrm{pH}$ values. The fraction of $\mathrm{Cr}(\mathrm{VI})$ was lower at $\mathrm{pH} 8$, with the application of the low $\mathrm{Fe}(\mathrm{II})$ dosage $(0.25 \mathrm{mg} / \mathrm{L})$. This indicates a lower inhibitory effect of $\mathrm{pH}$ value as compared to the application of lower Fe(II) dosages. In contrast, an efficient reduction (and removal) of $\mathrm{Cr}(\mathrm{VI})$ was shown to be possible at lower $\mathrm{pH}$ values $(7$ and 6.5). However, at higher $\mathrm{Fe}(\mathrm{II})$ dosages, a relatively high amount of $\mathrm{Cr}(\mathrm{III})$ still remained dissolved, representing an inhibition of the second reaction step at lower $\mathrm{pH}$ values (Figure 9). 


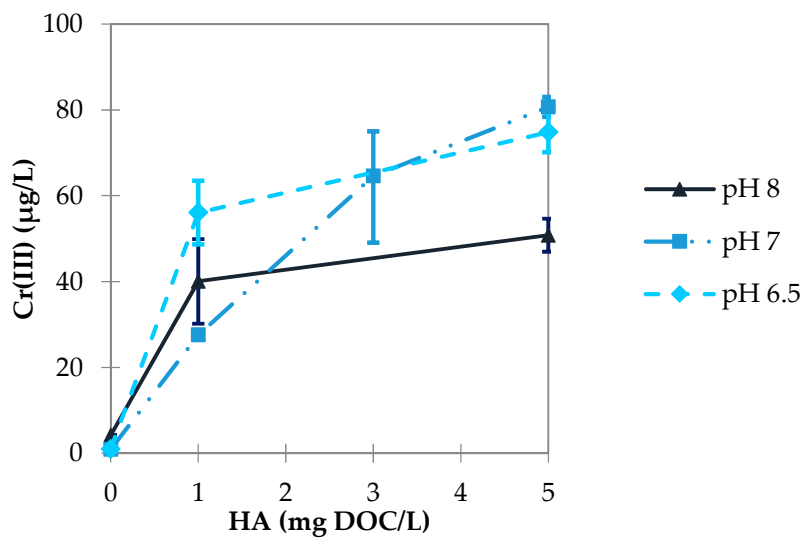

Figure 9. $\mathrm{Cr}$ (III) residual concentrations as a function of the presence of HAs (0, 1, 3, $5 \mathrm{mg}$ DOC/L) at $\mathrm{pH} 6.5,7$, and 8 and at $\mathrm{Fe}(\mathrm{II})$ dosage $2 \mathrm{mg} / \mathrm{L}$. Mean values with vertical bars indicate the respective range. The results were obtained by applying both set-ups A and $\mathrm{B}$.

\subsection{Cr(VI) Removal in Tap Water Containing NOM, Spiked with Cr(VI)}

To further determine if the results obtained with the artificial groundwater (NSF water) can be transferred to water containing natural organic matter, a first trial was conducted with the use of a water matrix of tap water containing NOM of $1.3 \mathrm{mg} / \mathrm{L}$. Due to the $\mathrm{pH}$ of the examined water (7.8), the results were compared with the results obtained using NSF water at $\mathrm{pH} 7$ and 8 and with HAs $(1 \mathrm{mg}$ $\mathrm{DOC} / \mathrm{L})$. Figure 10 shows that the reduction of $\mathrm{Cr}(\mathrm{VI})$ in the tap water was equally efficient when compared with NSF water at $\mathrm{pH} 8(16 \mu \mathrm{g} / \mathrm{L}$ residual $\mathrm{Cr}(\mathrm{VI})$ concentration in tap water, as compared with $17 \mu \mathrm{g} / \mathrm{L}$ in NSF water), but higher as compared with the respective residual concentrations at pH 7 in NSF water.

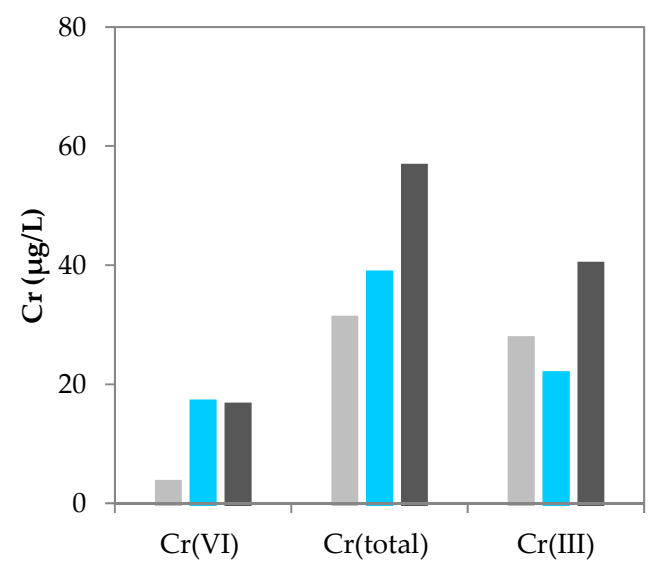

NSF-water, $1 \mathrm{mg}$ DOC/L, $\mathrm{pH} 7$

tap water, $1 \mathrm{mg} \mathrm{DOC/L,} \mathrm{pH} 7.8$

NSF-water, $1 \mathrm{mg}$ DOC/L, $\mathrm{pH} 8$

Figure 10. $\mathrm{Cr}(\mathrm{VI}), \mathrm{Cr}$ (total), and $\mathrm{Cr}(\mathrm{III})$ from tap water (pH 7.8, $1.3 \mathrm{mg}$ DOC/L) and from NSF water (pH 7 and $8,1 \mathrm{mg} \mathrm{DOC/L}$ ) at the Fe(II) dosage $2 \mathrm{mg} / \mathrm{L}$. All experiments were performed using set-up A.

Residual concentrations of $\mathrm{Cr}$ (total) were lower compared to the results in NSF water at $\mathrm{pH} 8$, which might be attributed to the slightly lower $\mathrm{pH}$ values. Certainly, the chemistry of Chromium removal depends also on the type of DOC which varies between natural waters and model humic substance.

\section{Conclusions}

$\mathrm{Fe}(\mathrm{II})$ reductive precipitation was confirmed to be an effective process for the removal of $100 \mu \mathrm{g} / \mathrm{L}$ $\mathrm{Cr}(\mathrm{VI})$ in the absence of HAs, at the $\mathrm{pH}$ range between 6.5 and 8 and for $\mathrm{Fe}(\mathrm{II})$ dosages $1 \mathrm{mg} / \mathrm{L}$ or higher. A significant effect of the $\mathrm{pH}$ value was only found when lower Fe(II) dosages ( 0.25 or 
$0.5 \mathrm{mg} / \mathrm{L}$ ) were applied. At these (lower) dosages, the residual $\mathrm{Cr}(\mathrm{VI})$ and $\mathrm{Cr}$ (total) concentrations increased at $\mathrm{pH} 8$ ( $\mathrm{Cr}$ (total) was also increased at lower $\mathrm{pH}$ value of 6.5). For all examined $\mathrm{pH}$ values, the highest residual concentrations were found for the lower Fe(II) dosage $(0.25 \mathrm{mg} / \mathrm{L})$. Moreover, the reduction of $\mathrm{Cr}(\mathrm{VI})$ was quite fast and practically completed within $4 \mathrm{~min}$ after the addition of $\mathrm{Fe}(\mathrm{II})$ for all the examined dosages of $\mathrm{Fe}$ (II). A rapid rate of removal of subsequently formed $\mathrm{Cr}$ (III) was also found for $\mathrm{Fe}(\mathrm{II})$ dosages $1 \mathrm{mg} / \mathrm{L}$ or higher, although this was decreased when the lower $\mathrm{Fe}(\mathrm{II})$ dosages $(0.25$ or $0.5 \mathrm{mg} / \mathrm{L})$ were applied. The removal of $\mathrm{Cr}(\mathrm{VI})$ in the presence of HAs showed residual concentrations below the (higher in this case) detection limit of $10 \mu \mathrm{g} / \mathrm{L}$, while the respective reductive reaction was strongly inhibited for the smaller examined Fe(II) dosage $(0.25 \mathrm{mg} / \mathrm{L})$.

The removal of $\mathrm{Cr}$ (total) was more inhibited by the presence of HAs as compared to $\mathrm{Cr}(\mathrm{VI})$. With $\mathrm{Fe}(\mathrm{II})$ dosages lower than $2 \mathrm{mg} / \mathrm{L}$, the residual chromium concentrations remained at levels around $60 \mu \mathrm{g} / \mathrm{L}$. At $\mathrm{Fe}(\mathrm{II})$ dosages 1 or $2 \mathrm{mg} / \mathrm{L}$, where the decrease of $\mathrm{Cr}(\mathrm{VI})$ concentrations below $10 \mu \mathrm{g} / \mathrm{L}$ is possible, the high residual concentrations of $\mathrm{Cr}$ (total) observed are mainly attributed to high residual $\mathrm{Cr}(\mathrm{III})$ concentrations. This coincides with relevant literature data, since a formation of soluble complexes between $\mathrm{Fe}(\mathrm{III}), \mathrm{Cr}(\mathrm{III})$ and organic substances is possible in this case.

Residual iron concentration was not measured in all experiments, so a reliable analysis concerning remaining iron concentration cannot be given. However, a tendency of higher iron content in organically loaded waters was seen, probably due to complexation reactions taking place between Fe and NOM. This issue is currently under further investigation.

The results from experiments using tap water containing natural organic matter spiked with $\mathrm{Cr}(\mathrm{VI})$ indicated that similar results were obtained when using artificial groundwater. While the removal of $\mathrm{Cr}(\mathrm{VI})$ was similar for both cases, $\mathrm{Cr}(\mathrm{III})$ was more efficiently removed from the natural water, eventually leading to lower $\mathrm{Cr}$ (total) concentrations.

The results of the current study demonstrated the necessity for further optimization of the treatment processes applied for $\mathrm{Cr}$ (total) removal, especially in the presence of HAs. During this process, the removal of $\mathrm{Cr}$ (III) was shown to be an important step of the process in the presence of HAs, which is indicated through the higher residual concentrations of $\mathrm{Cr}(\mathrm{III})$. Contrary, the removal of $\mathrm{Cr}(\mathrm{VI})$ seems to be less affected by the presence of HAs.

Acknowledgments: The authors are grateful to the financial contribution from the IKYDA 2016 program, ACr-Tech, which enabled the mobility of researchers between the Laboratories of Technical University Hamburg and Aristotle University of Thessaloniki. Special thanks to Stelios Stylianoy, Zoi Mantha, and Anastasia Tolkou for their support during the research exchanges in Thessaloniki, Greece and Hamburg, Germany.

Author Contributions: Anna Gröhlich, Margarethe Langer, Manassis Mitrakas, Anastasios Zouboulis, Ioannis Katsoyiannis, and Mathias Ernst conceived and designed the experiments; Anna Gröhlich performed the experiments; Anna Gröhlich and Margarethe Langer analysed the data; Manassis Mitrakas contributed analysis tools; Anna Gröhlich, Margarethe Langer, Manassis Mitrakas, Anastasios Zouboulis, Ioannis Katsoyiannis, and Mathias Ernst wrote the paper.

Conflicts of Interest: The authors declare no conflict of interest. The founding sponsors had no role in the design of the study; in the collection, analyses, or interpretation of data; in the writing of the manuscript, and in the decision to publish the results.

\section{References}

1. Kim, J.G.; Dixon, J.B. Oxidation and fate of chromium in soils. Soil Sci. Plant Nutr. 2002, 48, 483-490. [CrossRef]

2. Ludwig, A. Chrom(III) und Chrom(VI) in Einer mit Gerbereischlamm Belasteten Ackerfläche bei Weinheim. Master's Thesis, Universität Heidelberg, Heidelberg, Germany, 1996. [CrossRef]

3. Kaprara, E.; Kazakis, N.; Simeonidis, K.; Coles, S.; Zouboulis, A.I.; Samaras, P.; Mitrakas, M. Occurrence of $\mathrm{Cr}(\mathrm{VI})$ in drinking water of Greece and relation to the geological background. J. Hazard. Mater. 2015, 281, 2-11. [CrossRef] [PubMed] 
4. Kazakis, N.; Kantiranis, N.; Voudouris, K.S.; Mitrakas, M.; Kaprara, E.; Pavlou, A. Geogenic Cr oxidation on the surface of mafic minerals and the hydrogeological conditions influencing hexavalent chromium concentrations in groundwater. Sci. Total Environ. 2015, 514, 224-238. [CrossRef] [PubMed]

5. Costa, M. Potential hazards of hexavalent chromate in our drinking water. Toxicol. Appl. Pharmacol. 2003, 188, 1-5. [CrossRef]

6. McLean, J.E.; McNeill, L.S.; Edwards, M.; Parks, J.L. Hexavalent chromium review: Part 1, Health effects, regulations, and analysis. J. Am. Water Works Assoc. 2012, 104, E348-E357. [CrossRef]

7. Kotaś, J.; Stasicka, Z. Chromium occurrence in the environment and methods of its speciation. Environ. Pollut. 2000, 107, 263-283. [CrossRef]

8. Stumm, W. Aquatic Chemistry: Chemical Equilibria and Rates in Natural Waters, 3rd ed.; Wiley: New York, NY, USA, 1996; ISBN 0471511846.

9. McNeill, L.S.; McLean, J.E.; Parks, J.L.; Edwards, M. Hexavalent chromium review: Part 2: Chemistry, occurrence, and treatment. J. Am. Water Works Assoc. 2012, 104, E395-E405. [CrossRef]

10. Palmer, C.D.; Puls, R. EPA Ground Water Issue: Natural Attenuation of Hexavalent Chromium in Groundwater and Soils; Technology Innovation Office, Office of Solid Waste and Emergency Response, US EPA: Washington, DC, USA, 1994.

11. Council Directive 98/83/EC on the Quality of Water Intended for Human Consumption. 3 November 1998. Available online: http://eur-lex.europa.eu/legal-content/EN/TXT/?uri=celex:01998L0083-20151027 (accessed on 5 January 2017).

12. California Environmental Protection Agency. Chromium-6 Drinking Water MCL. 2016. Available online: http://www.waterboards.ca.gov/drinking_water/certlic/drinkingwater/Chromium6.shtml (accessed on 5 January 2017).

13. Mitrakas, M.G.; Pantazatou, A.S.; Tzimou-Tsitouridou, R.; Sikalidis, C.A. Influence of pH and temperature on $\mathrm{Cr}(\mathrm{VI})$ removal from a natural water using Fe(II): A pilot and full scale case study. Desalination Water Treat. 2011, 33, 77-85. [CrossRef]

14. Buerge, I.J.; Hug, S.J. Kinetics and pH dependence of chromium(VI) reduction by iron(II). Environ. Sci. Technol. 1997, 31, 1426-1432. [CrossRef]

15. Pettine, M.; D'Ottone, L.; Campanella, L.; Millero, F.J.; Passino, R. The reduction of chromium(VI) by iron(II) in aqueous solutions. Geochim. Cosmochim. Acta 1998, 62, 1509-1519. [CrossRef]

16. Fendorf, S.E.; Li, G. Kinetics of Chromate Reduction by Ferrous Iron. Environ. Sci. Technol. 1996, 30, 1614-1617. [CrossRef]

17. Schlautman, M.A.; Han, I. Effects of $\mathrm{pH}$ and dissolved oxygen on the reduction of hexavalent chromium by dissolved ferrous iron in poorly buffered aqueous systems. Water Res. 2001, 35, 1534-1546. [CrossRef]

18. El-Shoubary, Y.; Speizer, N.; Seth, S.; Savoia, H. A pilot plant to treat chromium-contaminated groundwater. Environ. Prog. 1998, 17, 209-213. [CrossRef]

19. Hering, J.G.; Lee, G. Removal of chromium(VI) from drinking water by redox-assisted coagulation with iron(II). J. Water Supply Res. Technol.-Aqua 2003, 52, 319-332.

20. Buerge, I.J.; Hug, S.J. Influence of organic ligands on chromium(VI) reduction by iron(II). Environ. Sci. Technol. 1998, 32, 2092-2099. [CrossRef]

21. Hori, M.; Shozugawa, K.; Matsuo, M. Reduction process of $\mathrm{Cr}(\mathrm{VI})$ by Fe(II) and humic acid analyzed using high time resolution XAFS analysis. J. Hazard. Mater. 2015, 285, 140-147. [CrossRef] [PubMed]

22. Agrawal, S.G.; Fimmen, R.L.; Chin, Y.-P. Reduction of $\mathrm{Cr}(\mathrm{VI})$ to $\mathrm{Cr}(\mathrm{III})$ by $\mathrm{Fe}(\mathrm{II})$ in the presence of fulvic acids and in lacustrine pore water. Chem. Geol. 2009, 262, 328-335. [CrossRef]

23. Jiang, W.; Cai, Q.; Xu, W.; Yang, M.; Cai, Y.; Dionysiou, D.D.; O'Shea, K.E. Cr(VI) Adsorption and Reduction by Humic Acid Coated on Magnetite. Environ. Sci. Technol. 2014, 48, 8078-8085. [CrossRef] [PubMed]

24. Wittbrodt, P.R.; Palmer, C.D. Effect of temperature, ionic strength, background electrolytes, and Fe(III) on the reduction of hexavalent chromium by soil humic substances. Environ. Sci. Technol. 1996, 30, 2470-2477. [CrossRef]

25. Amy, G.; Chen, H.; Drizo, A.; von Gunten, U.; Brandhuber, P.; Hund, R.; Chowdhury, Z.; Kommineni, S.; Sinha, S.; Jekel, M.; et al. Adsorbent Treatment Technologies for Arsenic Removal; Awwa Research Foundation, American Water Works Association: Denver, CO, USA, 2005; ISBN 1-58321-399-6.

26. DVGW. Arbeitsblatt W 218 Flockung in der Wasseraufbereitung-Flockungstestverfahren: DVGW W 218; DVGW Deutscher Verein des Gas- und Wasserfaches e.V.: Bonn, Germany, 1998; ISSN: 0176-3504. 
27. Rüdel, H.; Kösters, J.; Schörmann, J. Bestimmung von Elementgehalten in Umweltproben Durch ICP-MS. 2011. Available online: http://www.ime.fraunhofer.de/content/dam/ime/de/documents/AE/UPB_SOP_ ICP-MS_de.pdf (accessed on 5 January 2017).

28. EN 1233:1996: Water Quality-Determination of Chromium-Atomic Absorption Spectrometric Methods; European Committee for Standardization: Brussels, Belgium, 1996.

29. Eaton, A.D.; American Public Health Association; American Water Works Association; Water Pollution Control Federation (Eds.) Standard Methods for the Examination of Water and Wastewater, 21st ed.; American Public Health Association: Washington, WA, USA, 2005; ISBN 0875530478.

30. Sedlak, D.L.; Chan, P.G. Reduction of hexavalent chromium by ferrous iron. Geochim. Cosmochim. Acta 1997, 61, 2185-2192. [CrossRef]

31. Mertineit, S.; Raue, B.; Thoma, A.; Sacher, F. Studie zur Belastung von Trinkwasser in Deutschland mit Chromat; DVGW Deutscher Verein des Gas- und Wasserfaches e.V.: Bonn, Germany, 2013.

32. Lindsay, D.R.; Farley, K.J.; Carbonaro, R.F. Oxidation of $\mathrm{Cr}(\mathrm{III})$ to $\mathrm{Cr}(\mathrm{VI})$ during chlorination of drinking water. J. Environ. Monit. 2012, 14, 1789-1797. [CrossRef] [PubMed]

(C) 2017 by the authors. Licensee MDPI, Basel, Switzerland. This article is an open access article distributed under the terms and conditions of the Creative Commons Attribution (CC BY) license (http://creativecommons.org/licenses/by/4.0/). 